\title{
Taxonomy and new records of Graphidaceae lichens in Western Pangasinan, Northern Philippines
}

\author{
Weenalei T. Fajardo ${ }^{1,2}$ and Paulina A. Bawingan ${ }^{1}$
}

\begin{abstract}
There are limited studies on the diversity of Philippine lichenized fungi. This study collected and determined corticolous Graphidaceae from 38 collection sites in 10 municipalities of western Pangasinan province. The study found 35 Graphidaceae species belonging to 11 genera. Graphis is the dominant genus with 19 species. Other species belong to the genera Allographa (3 species) Fissurina (3), Phaeographis (3), while Austrotrema, Chapsa, Diorygma, Dyplolabia, Glyphis, Ocellularia, and Thelotrema had one species each. This taxonomic survey added 14 new records of Graphidaceae to the flora of western Pangasinan.
\end{abstract}

Keywords: Lichenized fungi, corticolous, crustose lichens, Ostropales

\section{Introduction}

Graphidaceae is the second largest family of lichenized fungi (Ascomycota) (Rivas-Plata et al. 2012; Lücking et al. 2017) and is the most speciose of tropical crustose lichens (Staiger 2002; Lücking 2009). The inclusion of the initially separate family Thelotremataceae (Mangold et al. 2008; RivasPlata et al. 2012) in the family Graphidaceae made the latter the dominant element of lichen communities with 2,161 accepted species belonging to 79 genera (Lücking et al. 2017). However, the currently circumscribed family is projected to have about 1,850 species due to the rapid rate of new lichen discoveries (Rivas-Plata \& Lücking 2013; Lücking et al. 2014). In fact, in 2014, an additional 175 new species of Graphidaceae were reported in one publication alone (Sohrabi et al. 2014).

There are many studies on Graphidaceae lichens all over the world, with most of them done in South America. Significant taxonomical contribution in the Philippines was done by Edvard August Vainio, the father of Philippine lichenology, which led to the description of 118 Graphidaceae in 1921 (Tabaquero et al.2013). There are currently 459

${ }^{1}$ School of Advanced Studies, Saint Louis University, Baguio City, 2601 Philippines

${ }^{2}$ Pangasinan State University, Lingayen Campus, Lingayen, Pangasinan 2401 Philippines

*Corresponding email: wfajardo@psu.edu.ph

Date Submitted: 11 July 2019

Date Accepted: 26 November 2019 described Graphidaceae in the country (Parnmen et al. 2012). Most recent surveys resulted in the characterization of six new species (Lumbsch et al. 2011; Tabaquero et al.2013; Rivas-Plata et al. 2014). In the northwestern part of Luzon in the Philippines (Region 1), an account on the Graphidaceae lichens was conducted only from the Hundred Islands National Park (HINP), Alaminos City, Pangasinan (Bawingan et al. 2014). The study reported 32 identified lichens, including 17 Graphidaceae belonging to the genera Diorygma, Fissurina, Graphis, Thecaria and Thelotrema. Except for this one study in the HINP, there are no other records of lichens in Pangasinan, in particular, the Graphidaceae microlichens, which are commonly found in semiexposed areas in tropical forests (Lücking et al. 2013).

Hence, this present study continued the inventory of Graphidaceae lichens in Pangasinan, specifically the corticolous Graphidaceae lichens or those that grow on the barks of trees. With the current pace of land-use change and conversion in Pangasinan, there is a need to study these organisms before they become endangered or extinct. Moreover, lichens act as biological indicators (Nimis et al. 1991, Rivas-Plata et al. 2008b) and are known for their medicinal uses (Singh 2011). Hence, there is a need to conserve and preserve them.

\section{Materials and Methods}

\section{Study Area and Sampling Sites}

The study area included 38 collection sites in 10 municipalities of western Pangasinan namely Agno, Alaminos, Anda, Bani, Bolinao, Burgos, Dasol, Infanta, Mabini and Sual. 
Sampling sites represent different ecological areas selected based on their accessibility, safety and security during the time of the visit. Local Department of Environment and Natural Resources (DENR) personnel guided the researchers in the selection of sampling sites. Field surveys were done subsequently after the approval of the municipal mayors.

The sampling sites included coastal tourism areas (beach and islands), riparian zones (rivers and falls), forest reserves, caves, and parks. Fig. 1 shows the various collection sites per locality. The quantitative transect sampling method was employed. Rare, conspicuous and cryptic groups are more likely collected by this type of sampling (Cáceres et al. 2007).

\section{Sampling Procedures}

Sampling in forested area. The collection was done from 10-15 lichen-rich trees along a $100 \mathrm{~m}$ distance parallel, but $5 \mathrm{~m}$ away from the main trail to a distance of $30 \mathrm{~m}$ inward; trees were $5 \mathrm{~m}$ apart (Tabaquero et al. 2013).

Sampling in coastal areas. At each location, two transects were laid out not less than $1 \mathrm{~km}$ apart. A $50 \mathrm{~m}$ transect trail was deployed perpendicular to the high tide line. Transect began at the upper limit of the rockweed zone and moved landward to the area at which terrestrial vascular plants or lichens were seen (Brodo \& Sloan 2004).

Sampling in the riparian zones of wetlands. Riverbanks and wetland areas were sampled similarly to coasts. However, the transect line started from the edge of the bank near the river moving landward (Brodo \& Sloan, 2004).

Sampling near the roads. A $15 \mathrm{~m}$ transect was placed parallel to the road. The collection was done on trees $5 \mathrm{~m}$ apart (Kłos et al., 2009).

\section{Lichen Phorophytes and Collection}

Lichen phorophytes were mostly native trees such as Antidesma bunius (Linn.) Sprengel, Calophyllum inophyllum Linn., Ficus glomerata Roxb., Shorea polysperma Merr., Terminalia catappa Linn. and Toona calantas Merill and Rolfe. Other species of trees found in the area were Acacia auriculiformis A. Cunn. ex Benth., Cocos nucifera L., Mangifera indica L., Syzygium cumini (L.) Skeels, Vitex parviflora Juss. and Tamarindus indica L. Older trees were selected for lichen collection because their trunks tend to have more diverse lichen flora compared to younger representatives (Lücking et al. 1996; Fritz et al.2009).

The selected phorophytes had the following characteristics: freestanding well-lit trees with inclination of the trunk not exceeding $10^{\circ}$; no evidence of disturbance or pathologies and damaged decorticated parts of the trunk (Nimis et al. 2000; Asta et al. 2002; Aprile et al. 2011); and the trunk did not have more than $25 \%$ cover of bryophytes (Castello \& Skert 2005).

A sampling grid (microplot) was laid onto the phorophyte consisting of four vertical ladders of $10 \mathrm{~cm} \times 50 \mathrm{~cm}$, each divided into five $10 \mathrm{~cm} \times 10 \mathrm{~cm}$ unit areas. Each of the four ladders was placed to one of the four cardinal directions (north, south, east, and west) with the base at $1.5 \mathrm{~m}$ high from the ground (Castello \& Skert 2005; Cáceres et al. 2007; Aprile et al. 2011). Collection sites and phorophytes were photographed using Nikon D3200 DSLR and Garmin GPSMAP 64sc, which were automatically geotagged.

The standard protocol for field collection was followed to avoid or cause minimal damage to the tree trunk (Nayaka 2014). Colorless nail polish was applied to scraped areas to prevent the entry of pathogenic organisms. At most three thalli per species per collection site were collected for morpho-anatomical examination and vouchering. Examination and segregation of specimens resulted in 1,232 lichen collections. The herbarium vouchers are deposited at the Pangasinan State University (PSU) -Lingayen Biology Laboratory.

\section{Lichen Characterization and Identification}

The features essential for species identification of Graphidaceae lichens are the following: color and texture of the thallus; characteristics of ascomata such as their morph, form, emergence, branching, color, disc color, presence of pruina, margin, striation, and color of the rim; carbonization of excipulum and hypothecium; inspersion of its hymenium; number of ascospores in every ascus; the shape, locule number, length and width, septation, color and color reaction to Iodine solution of ascospores; and presence of lichenic acid (Staiger 2002; Lücking et al. 2009; Tabaquero et al. 2013).

Thin free-hand sections of ascomata and other structures were made using a sharp razor blade (Joshi et al. 2018). The sections were placed in water on a plain slide and covered with a glass slip and examined under a compound microscope using a Motic binocular compound microscope (Speed Fair Co., Ltd, Hong Kong) with 400x magnification. All morphometric measurements (e.g. spore size) were done in water mounts under the compound microscope using a calibrated eyepiece with a total magnification of 400x. Photographs of images viewed under the oil immersion objective were taken using Huawei Nova5T smartphone.

Spot color tests were performed for the initial determination of the lichen acids present using $10 \%$ aqueous $\mathrm{KOH}$ solution (K test), an aqueous solution of $\mathrm{Ca}(\mathrm{ClO})_{2}(\mathrm{C}$ test), an ethanolic solution of paraphenylenediamine (P test), and Iodine solution (I test). The stability of the $\mathrm{KOH}$ was tested on Graphis persicina ascocarp; a color change to green in the 


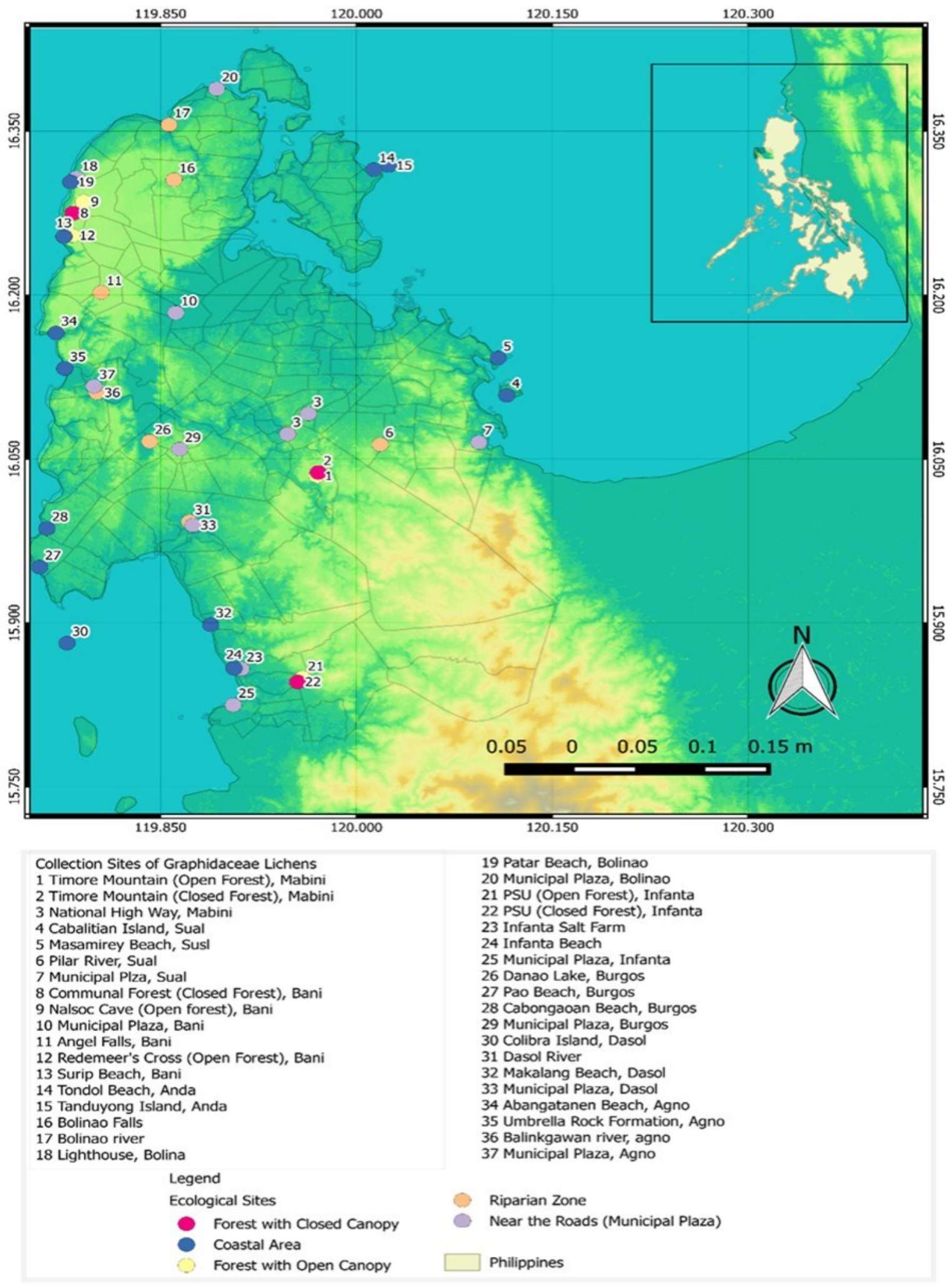

Figure 1. Map of the collection sites per locality in western Pangasinan. 
hymenium indicated a stable solution. A drop of each of these solutions was placed in separate areas on the thallus surface or the medulla then observed as to the color reactions (Hale 1967; Elix 1992). A color change to yellow using $\mathrm{K}$ test indicated the presence of stictic acid; under the microscope, this color change was observed as a yellow effusion along the thalline margin. A color change in the medulla from yellow to red in the $\mathrm{K}$ test indicated the presence of norstictic acid or salazinic acid. C test or $\mathrm{KC}+$ test showing a rose pink color change indicated the presence of gyrophoric acid. On the other hand, change in the color to blue-violet, red-violet upon addition of iodine solution indicated an amyloid property of ascospore or hymenium.

An extremely sensitive test done was observing crystal formation under the compound microscope (May et al. 2001). Thin sections of the thallus were placed on a glass slide and a drop of a reagent ( $\mathrm{K}$ or $\mathrm{P}$ ) was added to observe color reactions and the formation of crystals (Lücking 2009; Benatti 2012). Under the microscope, a $\mathrm{K}+$ yellow effusion without crystallization indicated the presence of stictic acid; the formation of long reddish needle-shaped crystals with a stellate formation indicated the presence of salazinic acid; norstictic acid crystals were shorter with no star-like formation. A P+ test that indicated the presence of protocetraric acid shows formation of red to deep red granules (not needle-shaped crystals).

Using the morpho-anatomic features and chemistry of the lichens, the collected specimens were identified using various taxonomic keys (Staiger 2002; Archer 2006, 2009; Sipman 2005, 2008a, 2008b; Rivas-Plata et al. 2008; Lücking et al. 2009, Rivas-Plata et al. 2010; Joshi et al. 2013; Lücking et al. 2014; Lücking et al. 2016). A key for the identification of the lichens in the Graphidaceae from western Pangasinan was prepared.

\section{Results}

Field collections in the 38 sampling sites in western Pangasinan led to the identification of 35 Graphidaceae species distributed in 11 genera (Table 1). There were four thelotremoid genera comprised of Austrotrema, Chapsa, Ocellularia and Thelotrema. Most of the identified Graphidaceae were graphidoid lichens with 31 species belonging to the genera Allographa, Diorygma, Dyplolabia, Fissurina, Glyphis, Graphis and Phaeographis. Graphis was the dominant genus with 17 identified species and 2 unidentified. This total number of species indicated low species richness considering the large number of sampling areas. Evaluation of existing publications on Graphidaceae lichens showed that 14 new records (indicated with an asterisk) are included in this study.

\section{Thelotremoid Graphidaceae}

\section{Genus Austrotrema}

It is a new genus described by Medeiros et al. (2017). The genus name refers to the occurrence of the type species in the Australian-Southeast Asian region. The genus is circumscribed by small, pore-like apothecia with double margin, non-amyloid to faintly amyloid ( $\mathrm{I}+$ ) ascospores, and presence of stictic acid (Medeiros et al. 2017).

*Austrotrema bicinctulum (Nyl.) I. Medeiros, Lücking \& Lumbsch (2017)

It was formerly placed under the genus Thelotrema but was separated due to molecular phylogenetic evidence (Medeiros et al. 2017). A. bicinctulum was previously collected in Thailand (Schumm \& Aptroot 2012; Buaruang et al. 2017). It has lepadinoid ascocarp, which is immersed to erumpent with free excipulum and double margin (Rivas-Plata et al., 2010). Its ascospores are transversely septate, hyaline and non-amyloid (I), $18-23 \times 5-8 \mu \mathrm{m}$ in size with $8-10$ locule. Stictic acid (K+Y, P-, C-) present. (Fig. 2a)

\section{Genus Chapsa}

The genus Chapsa was described in 1860 (Joshi et al. 2018); however, the group was brought up lately by Frisch et al. (2006) to include species earlier classified in Thelotrema, Chroodiscus, Ocellularia, and Myriotrema. The genus Chapsa accommodates a group of thelotremoid lichens with a trentepohlioid photobiont, chroodiscoid ascomata, an exciple with lateral paraphyses, and almost thin- to thick-walled ascospores (Messuti et al. 2010). It comprises 62 species with pantropical or subtropical distribution (Lücking et al. 2017).

\section{*Chapsa indica A. Massal. (1860)}

The species has records in Australia, Brazil, Guyana, Malaysia, Singapore and Thailand (Lumbsch et al. 2014; The Catalogue of Life Partnership 2018). C. indica is recognized by its leprocarpoid ascomata with brown disc covered by thick white-felty pruina. This type of ascomata is immersed to erumpent with irregular almost erect marginal lobes that usually break apart (Rivas-Plata et al. 2010). Its hymenium is nonamyloid. Ascospores are transversely septate, hyaline and nonamyloid (I-), 39-91 x 5-8 $\mu \mathrm{m}$ in size with 25-27 locules. No lichenic acid (K-, P-, C-) detected. (Fig. 2b)

\section{Genus Ocellularia}

Ocellularia is the largest genus in the Graphidaceae after 
Table 1. Graphidaceae microlichens in Western Pangasinan

\begin{tabular}{|c|c|}
\hline Genera & Graphidaceae species \\
\hline Allographa Chevall. (1824) & $\begin{array}{l}\text { Allographa fujianensis (Z.F.Jia \& J.C.Wei) } \\
\text { Lücking \& Kalb (2018) } \\
\text { Allographa laubertiana (Fée) Lücking \& Kalb (2018) } \\
\text { Allographa pilarensis (Cáceres \& Lücking) } \\
\text { Lücking \& Kalb (2018) }\end{array}$ \\
\hline Austrotrema I. Medeiros, Lucking & Austrotrema bicinctulum (Nyl.) \\
\hline$\& \operatorname{Lumbsch}(2017)$ & I. Medeiros, Lucking \& Lumbsch (2017) \\
\hline Chapsa A.Massal. (1860) & Chapsa indica A. Massal. (1860) \\
\hline Diorygma Eschweiler (1824) & $\begin{array}{l}\text { Diorygma hieroglyphicum (Pers.) } \\
\text { Staiger \& Kalb (2004) }\end{array}$ \\
\hline Dyplolabia A.Massal. (1854) & Dyplolabia afzelii (Ach.) A. Massal. (1854) \\
\hline Fissurina Fée (1825) & $\begin{array}{l}\text { Fissurina comparilis (Nyl.) Nyl. (1888) } \\
\text { F. “chroodiscoides” Sipman (2008) } \\
\text { Fissurina sp. }\end{array}$ \\
\hline Glyphis Ach. (1814) & Glyphis scyphulifera (Ach) Staiger (2002) \\
\hline Graphis Adans. (1763) & $\begin{array}{l}\text { Graphis analoga (Nyl.) Zahlbr. (1909) } \\
\text { G. cincta (Pers.) Aptroot (2009) } \\
\text { G. consimilis Vain (1907) } \\
\text { G. dendrogramma Nyl. (1875) } \\
\text { G. distincta Makhija \& Adaw. (2005) } \\
\text { G. furcata Fée (1825) } \\
\text { G. glaucescens Fée (1824) } \\
\text { G. immersicans Archer (2001) } \\
\text { G. imshaugii M. Wirth \& Hale (1978) } \\
\text { G. leptocarpa Fée (1824) } \\
\text { G. lineola Ach. (1810) } \\
\text { G. modesta Zahlbr. (1911) } \\
\text { G. nanodes Vain. (1921) } \\
\text { G. nilgiriensis Adaw. \& Makhija (2006) } \\
\text { G. persicina G. Mey. \& Flot. (1843) } \\
\text { G. pinicola Zahlbr. (1930) } \\
\text { G. sundarbanensis Jagadeesh Ram \& G. P. Sinha (2007) } \\
\text { Graphis sp.1 } \\
\text { Graphis sp. } 2\end{array}$ \\
\hline Ocellularia G. Mey (1825) & Ocellularia lumbschii S. Joshi \& Hur (2015) \\
\hline Phaeographis Müll. Arg. (1882) & $\begin{array}{l}\text { Phaeographis caesioradians } \\
\text { (Leight.) A.W. Archer (2005) } \\
\text { P. intricans (Nyl). Staiger (2002) } \\
\text { P. nylanderi (Vain.) Zahlbr. (1923) }\end{array}$ \\
\hline Thelotrema Ach. (1803) & Thelotrema adjectum Nyl. (1886) \\
\hline
\end{tabular}




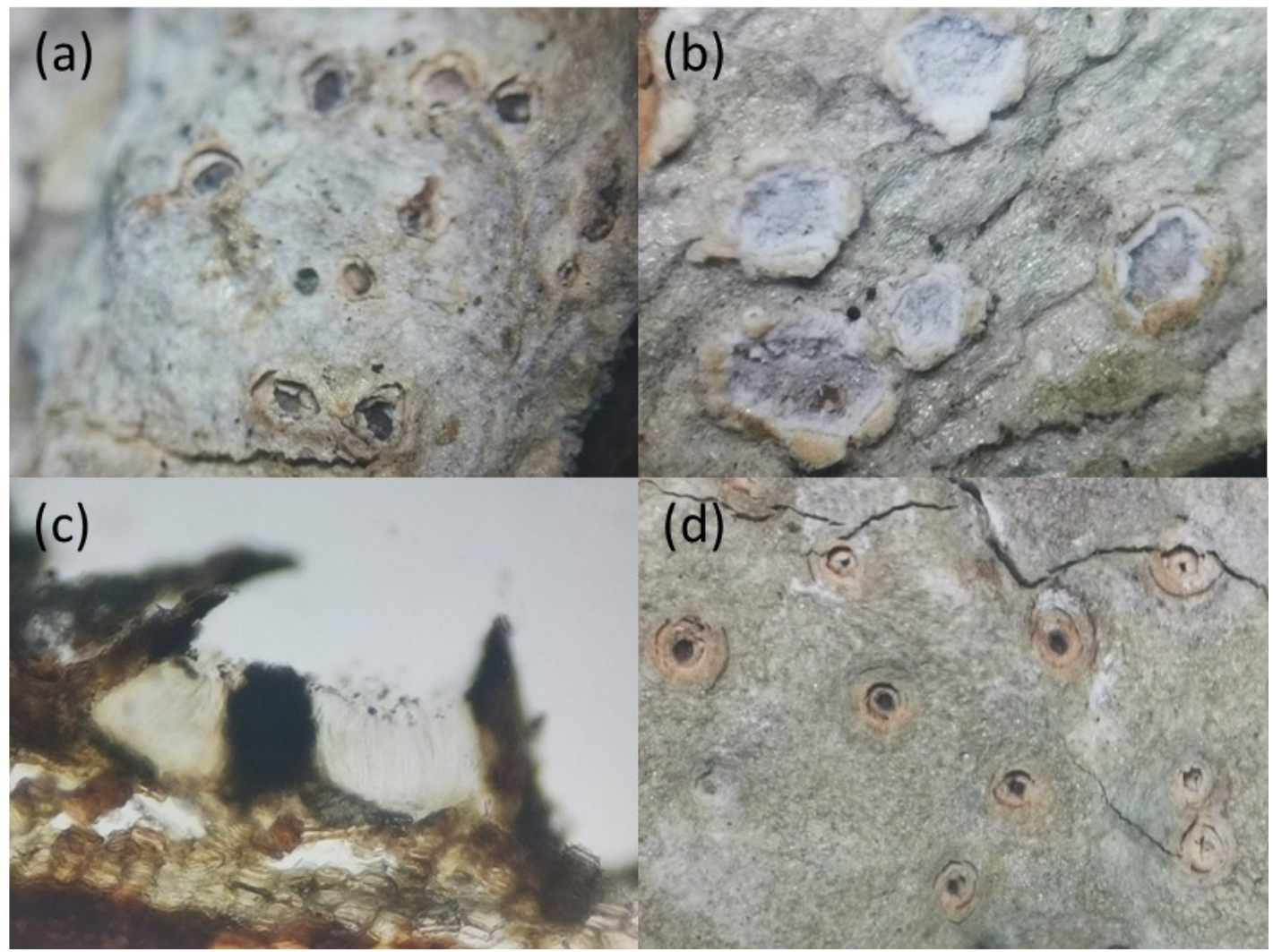

Figure 2. Morphoanatomical features of thelotrematoid Graphidaceae under stereomicroscope (20x) and compound light microscope (400x). (a) A. bicinctulum lepadinoid ascomata (b) C. indica chroodiscoid ascomata (c) Longitudinal section of $O$. lumbschii ascomata showing apically carbonized columella and excipulum (d) T. adjectum lepadinoid ascomata.

Graphis, with 400 currently recognized species (Lücking et al. 2017). The genus is characterized by having a brown to carbonized excipulum lacking periphysoid and a carbonized columella (da Silva Cáceres 2006).

\section{*Ocellularia lumbschii S. Joshi \& Hur (2015)}

It was first collected in Vietnam (Joshi et al. 2015). This species has ocellularioid ascocarp, clear hymenium, apically carbonized exciple, and apically carbonized columella. Ascospores are transversely septate, hyaline and amyloid (I+), 15-29 $\times$ 7-8 $\mu \mathrm{m}$ in size with 4-10 locules. Stictic acid (K+Y, P-, C-) present. (Fig. 2c)

\section{Genus Thelotrema}

There are 106 acknowledged species of Thelotrema worldwide (Lücking et al. 2017). The genus Thelotrema is circumscribed by the lepadinoid or rarely urceolarioid or ocellularioid apothecia, with more or less free excipulum and a distinct split between excipulum and thalline margin, thalline margin usually entire but free excipulum often undulate to fissured; ascospores often with thick wall (Rivas-Plata et al. 2010)

\section{*Thelotrema adjectum Nyl. (1886)}

It has records in Cuba, India, and the USA (The Catalogue of Life Partnership 2018). It is recognized by round and immersed ascocarps with flesh-colored inner excipulum, small and roundish to irregular pores. It has clear hymenium, hyaline and amyloid (I+ red-violet) muriform ascospores with 31-47 x 5 $-8 \mu \mathrm{m}$ size and 10-12 x 2-4 locules. No lichen acid (K-, P-, C-) detected. (Fig. 2d)

\section{Graphidoid Graphidaceae}

\section{Genus Allographa}

The formal placement of Allographa into the Graphidaceae led to the transfer of 182 Graphis and Hemithecium species in this genus (Lücking \& Kalb, 2018). Species under the genus have usually simple, prominent, broader, completely carbonized and often with striate lirellae. They have large ascospores with numerous septa and exhibit type B (asci and ascospores hardly discernible because of large and irregular oil droplets) hymenium inspersion (Lücking et al. 2017). However, no 


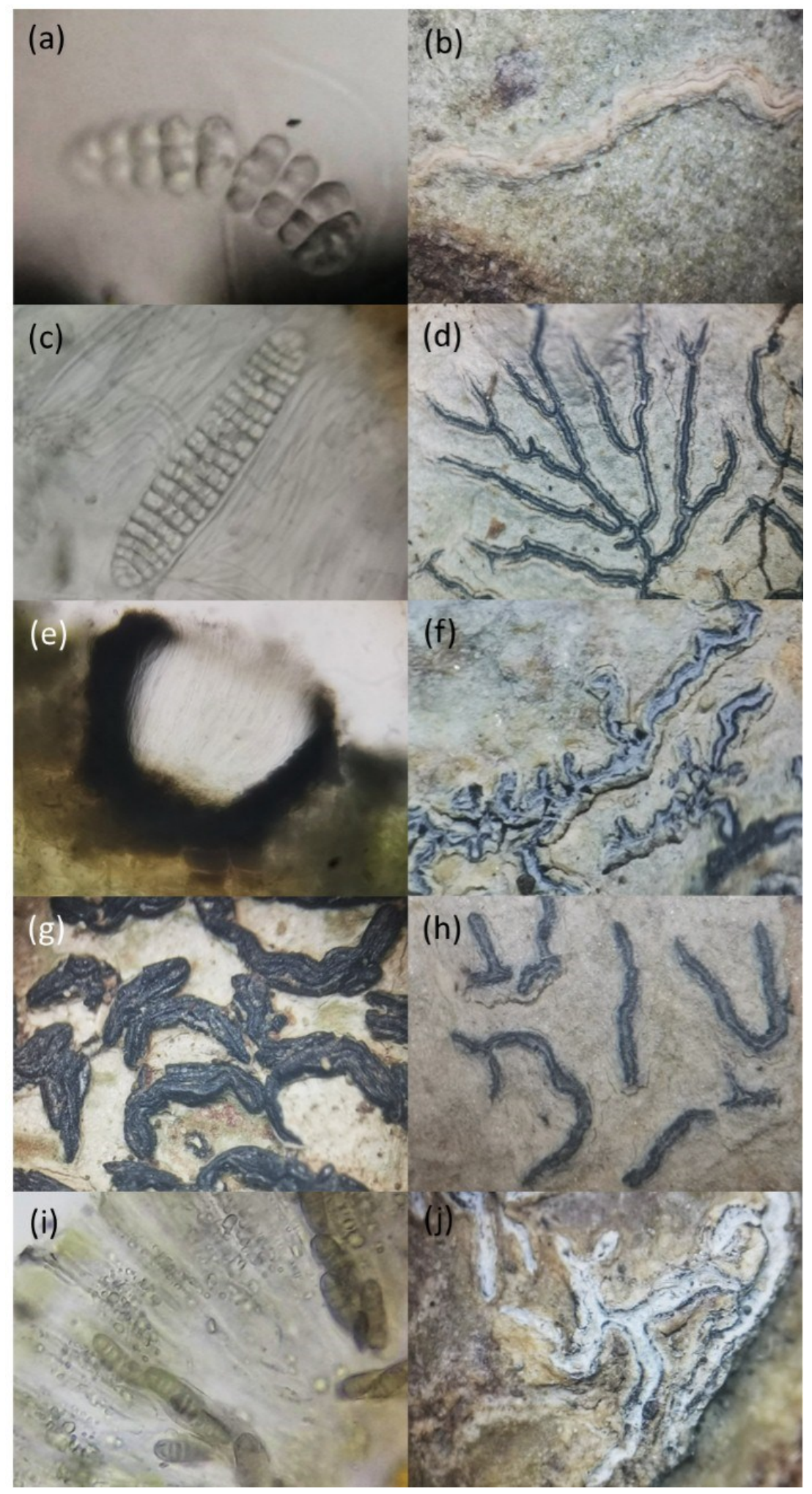

Figure 3. Morphoanatomical features of graphidoid Graphidaceae under stereomicroscope (20x) and compound light microscope (400x). (a) muriform ascospore of A. fujianensis (b) uncarbonized lirella of A. laubertiana (c) muriform ascospore of $A$. pilarensis (d) radiately branched lirellae of $G$. imshaugii (e) completely carbonized excipulum of $G$. imshaugii (f) scripta morph of lirellae of G. modesta (g) striated lirellae of G. nilgiriensis (g) scripta morph of lirellae of $G$. sundarbanensis (h) brown ascospore in inspersed hymenium of $P$. nylanderi (i) uncarbonized lirellae with pruinose disc of $P$. caesioradians. 
particular character or certain combination of characters would easily demarcate these genera. We have three species with new records, namely $A$. fujianensis with a record in China, $A$. laubertiana documented in Australia, Dominica and Peru (Staiger 2002; Archer 2009) and A. pilarensis in Brazil (The Catalogue of Life Partnership 2018).

\section{*Allographa fujianensis (Z.F.Jia \& J.C.Wei) Lücking \& Kalb (2018)}

The lirella of this species has hossei-morph characterized by erumpent to prominent and sparsely branched entire labia with basal thalline margin (Rivas-Plata et al. 2010). It has also clear hymenium, completely carbonized exciple, hyaline and amyloid (I+) muriform ascospores with 23-39 x10-13 $\mu$ m size and 8-10 x 2-4 locules. Stictic acid (K+Y, P-, C-) present. (Fig. 3a)

\section{*Allographa laubertiana (Fée) Lücking \& Kalb (2018)}

It is characterized by lirellate ascomata with raised thalline margins concolorous with the thallus. It has clear hymenium and non-carbonized exciple. Ascospores are hyaline, amyloid (I+) transversely septate with $26-42 \times 7-8 \mu \mathrm{m}$ size and 8-14 locules. No lichenic acid (K-, P- \& C-) detected. (Fig. 3b)

\section{*Allographa pilarensis Cáceres \& Lücking (2007)}

It has ascocarps that are negrosina-morph characterized by prominent complete thin thalline margin and sparsely branched lirellae. The hymenium is inspersed and with laterally carbonized exciple. Ascospores are hyaline and amyloid (I+) muriform with $78-96 \times 21-24 \mu \mathrm{m}$ size and $>8 \times 2-4$ locules. No lichenic acid detected. (Fig. 3c)

\section{Genus Diorygma}

The genus has 71 species (Lücking et al., 2017), widely distributed in tropical to subtropical regions. The characteristics of the taxon are inconspicuous pseudocortex resulting in a matt, granular and farinose upper surface (ecorticate); ascocarps are lirellate with heavily pruinose disc (Meng \& Wei 2008). The exciple and hypothecium are non-carbonized, clear jelly with tough hymenium, one to two ascospores per ascus, ascospores bean-ellipsoidal, muriform, I+ blue-violet. Secondary chemistry includes stictic acid or norstictic acid $(\mathrm{K}+\mathrm{Y}$, or $\mathrm{K}+\mathrm{Y}$ turning red) (Sipman 2008a; Tabaquero et al. 2013).

\section{Diorygma hieroglyphicum (Pers.) Staiger \& Kalb (2004)}

It is recognized by branched lirellate ascocarp, immersed with exposed disc covered with whitish to brownish pruina, epithecium covered with a thick brown layer. The hymenium is clear and amyloid (I+ blue). Ascospores are hyaline and amyloid (I+ blue-violet), muriform, large in size, 44-130 x 15$26 \mu \mathrm{m},<8 \times 2-4$ locules. Stictic acid (K+Y, P-, C-) present.

\section{Genus Dyplolabia}

This genus, initially placed under Graphis is distinguished by the erumpent to prominent ascomata forming labia, with thick carbonization and thick white cover containing lecanoric acid (Kalb et al. 2016). Ascospores are hyaline and nonamyloid (I-) with 3-septate lenticular lumina (Sipman 2008a). There are only four known species of Dyplolabia (Lücking et al. 2017). Of these four, the Philippines has contributed one new species, Dyplolabia dalywaiana described in 2016 with the type specimen coming from Mt. Palali, Nueva Vizcaya (Kalb et al. 2016).

\section{Dyplolabia afzelii (Ach.) A. Massal. (1854)}

It has lateral carbonization with labia thickly pruinose. Ascospores are transversely septate with $13-26 \times 7-8 \mu \mathrm{m}$ size and 4-locule or 3-septate. Lecanoric acid is present in the pruina of the ascocarp (K-, P-, C+ red).

\section{Genus Fissurina}

Fissurina comprises 160 species worldwide (Lücking et al. 2017). Many species have recently been added to the genus as a consequence of a molecular and phylogenetic revision of the Graphidaceae (Rivas-Plata et al. 2012a). The genus accommodates species with mostly slit-like lirellae (Archer 2009; Staiger 2002).

\section{Fissurina comparilis (Nyl.) Nyl. (1888)}

This is recognized by elongate ascocarp seemingly labiate, however, fissurinoid with thin, dark-brownish margins and closed above the disc. Ascospores are hyaline to faintly brown, transversely septate with $10-16 \times 7-8 \mu \mathrm{m}$ size and 4-locules. Stictic acid (K+Y, P-, C-) present.

\section{Fissurina "chroodiscoides" Sipman (2008)}

The ascocarp of this species is dumastii-type, which is concolorous with thallus outside and conspicuously white inside. Ascospores are hyaline, non-amyloid (I-) muriform with $20-26 \times 10-11 \mu \mathrm{m}$ size and 6-8 $\times 2-3$ locule. No lichen acids detected.

\section{Fissurina sp. 1}

This species is distinguished by aggregate, radiate lirellae, forming a pseudostroma (ascocarp with several discs) with inconspicuous and gaping labia. Ascospores are hyaline to faintly brown, amyloid (I+ blue-violet) transversely septate with 15-17 x 7-8 $\mu \mathrm{m}$ size and 4-locules. No lichen acid detected. 


\section{Genus Glyphis}

The genus contains seven known species (Lücking et al. 2017). The distinguishing features under the genus include exposed disc, with brown powdery cover (brown pruina) and anastomosing paraphyses. Hymenium is clear with brown granular tips and thick jelly-like walls (Staiger 2005; Sipman 2008a). Ascospores are continuously hyaline.

\section{Glyphis scyphulifera (Ach) Staiger (2002)}

This species is recognized by rounded sessile ascocarps with dark brown disc; hyaline, I+ blue-violet muriform ascospores, 26-29 x 10-13 $\mu \mathrm{m}$ size, $8-10 \times 2-4$ locules. No lichen acid detected.

\section{Genus Graphis}

Recent molecular and data mining placed 271 species of Graphis in the core Graphidaceae (Lücking et al. 2018). The thallus of Graphis is white-gray caused by abundant calcium oxalate crystals in or above the photobiont layer, a more or less prosoplectenchymatous cortex, extremely rarely sorediate or insidiate, but having distinctly lirellate apothecia (Lücking 2009). Various species of the genus are distinguished by the lirella morph combinations, spore characteristics, and chemistry. We have seven (7) new records out of the 19 species for Graphis, namely: G. distincta with previous records only in India (Lücking et al. 2009); G. imshaugii previously known only in New Mexico; G. modesta in Solomon Islands and India; G. nilgiriensis in India and G. sundarbanensis documented from Brazil, Fiji, Papua, Seychelles and Vanuatu (The Catalogue of Life Partnership 2018).

\section{Graphis analoga (Nyl.) Zahlbr. (1909)}

It is characterized by erumpent to prominent, sparsely to irregularly branched lirellae (hossei-morph), clear hymenium, lateral carbonization of exciple, hyaline and amyloid (I+) muriform ascospores, 21-26 × 7-8 $\mu \mathrm{m}$ size and 4-6 $\times$ 2-4 locules. Norstictic acid present $(\mathrm{K}+\mathrm{Y}$ then forming red crystals with no star-like formation, $\mathrm{P}-, \mathrm{C}-$ ).

\section{Graphis cincta (Pers.) Aptroot (2009)}

It has lineola-morph lirellae characterized by short and sparsely branched ascocarp with lateral thalline margin, concealed disc and entire non-pruinose labia (Lücking et al. 2009). It has inspersed hymenium, laterally carbonized exciple, hyaline and amyloid (I+) transversely septate ascospores, 26-39 x 13-16 $\mu \mathrm{m}$ size, 8-10x 2-4 locules. Norstictic acid present.

Graphis consimilis Vain. (1907)
It is distinguished by erumpent to prominent, sparsely to irregularly branched lirellae (hossei-morph), clear hymenium, laterally carbonized exciple, hyaline and amyloid (I+) muriform ascospores with 20-42 x 13-16 $\mu \mathrm{m}$ size and 8-10x 2-3 locules. No lichen acid detected.

\section{Graphis dendrogramma Nyl. (1875)}

It has caesiella to dendrogramma-morph ascocarp characterized by radiately branched lirellae, concealed disc and non-pruinose entire labia. It has also clear hymenium, laterally carbonized exciple, hyaline and amyloid (I+) transversely septate ascospores with 15-31 x 7-8 $\mu \mathrm{m}$ size and 6-10 locules. Stictic acid present (K+Y, P-, C-).

\section{*Graphis distincta Makhija \& Adaw. (2005)}

It has scripta-morph ascocarps characterized by sparsely or radiately lirellae, exposed disc and pruinose entire labia. It has clear hymenium, laterally carbonized exciple, hyaline and amyloid (I+) transversely septate ascospores with $18-21 \mu \mathrm{m}$ size and 6-8 locules. Stictic and protocetraric acids detected $(\mathrm{K}+\mathrm{Y}$, $\mathrm{P}+, \mathrm{C}-)$.

\section{Graphis furcata Fée (1825)}

It is recognized by corticated thallus, sparsely to irregularly branched lirellae, immersed to erumpent, with lateral thalline margin, pruinose entire labia, concealed disc (caesiella-morph ascocarp), clear hymenium, lateral carbonization of exciple, hyaline and amyloid (I+) transversely septate ascospores with 18 $-26 \times 7-8 \mu \mathrm{m}$ size and 8-10 locules. No lichenic acid detected.

\section{Graphis glaucescens Fée (1824)}

It has glaucescens-morph ascocarps characterized by erumpent to prominent, sparsely to irregularly branched lirellae, concealed disc and pruinose entire labia. It is recognized also by its clear hymenium, apically carbonized exciple, hyaline and amyloid (I+) transversely septate ascospore with $31-45 \times$ 7-8 $\mu \mathrm{m}$ size and 8-10 locules. No lichenic acid detected.

\section{Graphis immersicans Archer (2001)}

Ascocarps are lineola to deserpens-morph, disc not exposed, clear hymenium, completely carbonized exciple, hyaline and amyloid (I+) transversely septate ascospores with 18 $-29 \times 7-8 \mu \mathrm{m}$ size and 6-8 locules. No lichenic acid detected.

\section{*Graphis imshaugii M. Wirth \& Hale (1978)}

It has very long and radiately branching lirellae (dendrogramma-morph), labia pruinose, disc concealed, clear hymenium, completely carbonized exciple, hyaline and amyloid (I+) transversely septate ascospores with $13-31 \times 7-8 \mu \mathrm{m}$ size 
and 6-8 locules. Stictic acid present. (Figs. 3d, 3e)

\section{Graphis leptocarpa Fée (1824)}

Ascocarps are lineola-morph, disc not exposed, inspersed hymenium, laterally carbonized exciple, hyaline and amyloid (I+) transversely septate ascospores with 23-26 x 7-8 $\mu \mathrm{m}$ size, 6 -8 locules. Stictic acid present.

\section{Graphis lineola Ach. (1810)}

Ascocarps are lineola-morph, disc not exposed, inspersed hymenium, laterally carbonized exciple, hyaline and amyloid (I+) transversely septate ascospores with $23-31 \times 7-8 \mu \mathrm{m}$ size, 8 -10 locules. No lichen acid detected.

\section{*Graphis modesta Zahlbr. (1911)}

It has ascocarps that are either dendrogramma- or lineolamorph, clear hymenium, completely carbonized exciple, hyaline and amyloid $(\mathrm{I}+)$ transversely septate ascospore with $15-21 \times 7-$ $10 \mu \mathrm{m}$ size, 8-10 locules. Stictic acid (K+Y, P-, C-) present. (Fig. 3f)

\section{Graphis nanodes Vain. (1921)}

Ascocarps are lineola-morph, clear hymenium, laterally carbonized exciple, hyaline and amyloid (I+) muriform ascospores with $26-39 \times 10-13 \mu \mathrm{m}$ size, $8-10 \times 2-4$ locules. No lichen acid detected.

\section{*Graphis nilgiriensis Adaw. \& Makhija (2006)}

It has striatula-morph ascocarp characterized by prominent, sparsely branched lirellae lacking thalline margin, concealed disc and non-pruinose striated labia. It has also clear hymenium, completely carbonized exciple, hyaline and amyloid (I+) transversely septate ascospores with $18-26 \times 5-6 \mu \mathrm{m}$ size, 8 -10 locules. Stictic acid present. (Fig. 3g)

\section{Graphis persicina G. Mey. \& Flot. (1843)}

It is recognized by its negrosina-morph lirellae, hymenium and epithecium inspersed with red pigments, laterally carbonized exciple, hyaline and amyloid (I+) transversely septate ascospores with 26-44 x 7-10 $\mu \mathrm{m}$ size, 9-15 locules. Isohypocrelline present ( $\mathrm{K}+$ Green, $\mathrm{P}-, \mathrm{C}-)$.

\section{Graphis pinicola Zahlbr. (1930)}

It is recognized by its lineola-morph lirellae, clear hymenium, laterally carbonized exciple, hyaline and amyloid (I+) transversely septate ascospores with 15-34 x 7-8 $\mu \mathrm{m}$ size, 6 -10 locules. No lichenic acid detected.

*Graphis sundarbanensis Jagadeesh Ram \& G. P. Sinha (2007)
It is identified by its scripta-morph lirellae, exposed disc, clear hymenium, laterally carbonized exciple, hyaline and amyloid (I+) transversely septate ascospores with $18-23 \times 7-8$ $\mu \mathrm{m}$ size, 8-14 locules. Stictic acid detected. (Fig. 3h)

\section{Graphis sp 1.}

It has negrosina-morph ascocarps with discs widely exposed. The hymenium and epithecium are inspersed with red pigments. Ascospores are hyaline, amyloid (I+) transversely septate with 28-56 x 7-8 $\mu \mathrm{m}$ size, 8-15 locules. Isohypocrelline (K+ Green, P-, C-) present.

\section{Graphis sp. 2}

It has lineola-morph, immersed with simple to sparsely branched lirellae sometimes separated by thallus by slits. It is also characterized by clear hymenium, laterally carbonized exciple, and hyaline amyloid (I+) transversely septate ascospores with $26-31 \times 5-8 \mu \mathrm{m}$ size, $8-10$ locules. Stictic and protocetraric acid detected $(\mathrm{K}+\mathrm{Y}, \mathrm{P}+, \mathrm{C}-)$.

\section{Genus Phaeographis}

The genus Phaeographis with 180 species of lichens (Lücking et al. 2017) is characterized by simple to irregularly branched, rarely discoid, open lirelliform ascomata, disc pruinose or epruinose. We have two new records: Phaeographis caesioradians (Leight.) A.W. Archer (2005) previously known only in the Dominican Republic, Indonesia, Malaysia, Papua New Guinea, and Singapore and, Phaeographis nylanderi (Vain.) Zahbr. (1923) collected only in Singapore and Taiwan (Aptroot \& Sparrius 2011; The Catalogue of Life Partnership 2018).

\section{*Phaeographis caesioradians (Leight.) A.W. Archer (2005)}

It is recognized by its stellate branched ascocarps with margins forming a whitish rim around the exposed, grey, flat disc. It has also clear hymenium, hyaline to light brown, muriform ascospores, $28-34 \times 10-16 \mu \mathrm{m}, 4-6 \times 1-2$ locule. No lichen acid detected. (Fig. 3i)

\section{Phaeographis intricans (Nyl). Staiger (2002)}

Ascocarps are densely stellate-branched, raised, stromatoid, widely exposed, grey flat disc. It has clear hymenium, non-carbonized exciple, hyaline to light brown transversely septate ascospores, $15-18 \times 5-8 \mu \mathrm{m}, 4$ locules. Norstictic acid present.

\section{* Phaeographis nylanderi (Vain.) Zahlbr. (1923)}

Ascocarps are round to slightly elongate, branched, with raised margins forming a dark rim around the widely exposed, 


\section{Key to the species of Graphidaceae lichens in Western Pangasinan}

1a Ascomata elongate, sometimes rounded, excipulum hyaline to carbonized, usually prosoplectenchymatous, periphysoids often absent

2 (Graphidoid-type)

$1 \mathrm{~b}$ Ascomata rounded to rarely elongate, excipulum hyaline, rarely carbonized, usually paraplectenchymatous, periphysoids often present 31(Thelotremoid-type)

2a Apothecia rounded to elongate, opening by irregular cracks in thallus, resulting in irregularly-shaped ascocarp when mature (fissurinoid)

$2 \mathrm{~b}$ Apothecia not fissurinoid

3a Ascospores transversely-septate 4

3b Ascocarp immersed, spores muriform, no lichen acids detected Fissurina "chroodiscoides"

4a Ascocarp pseudostromatous, labia inconspicuous and gaping, spores 15-17 x 7-8 $\mu \mathrm{m}$ Fissurina sp.

4b Ascocarp not pseudostromatous, labia partly carbonized, spores 10-16 x 7-8 $\mu \mathrm{m}$ Fissurina comparilis 5a Ascocarp sessile, rounded, disc pruinose brown, spores muriform, no lichen acids detected Glyphis scyphulifera

$5 b$ Ascocarp lirellate, ascospores transversely septate to muriform, may contain lichenic acids 6 6a Lirellae with open disc, hymenium I+ blue, spores murifom and large, 44-130 x 15-26 $\mu \mathrm{m}$ Diorygma hieroglyphicum

$6 \mathrm{~b}$ Lirellae open to exposed disc, hymenium I-, spores muriform to transversely septate, not as large 7

7a Lirellae non-carbonized 8

$7 \mathrm{~b}$ Lirellae carbonized

8a Lirellae elongate, simple and prominent, spores transversely septate, 26-42 x 7-8 $\mu \mathrm{m}, 8-14$ locules Allographa laubertiana

$8 \mathrm{~b}$ Lirellae rounded to stellate-branched, spores transversely septate to muriform 9

9a Lirellae stellate-branched 10

$9 \mathrm{~b}$ Lirellae rounded to slightly elongate, not stellate-branched, spores muriform 10a Spores muriform, brown, 28-34 x 10-16 $\mu \mathrm{m}$ Phaeographis nylanderi

10b Spores transversely septate, hyaline to faintly brown, $15-18 \times 5-8 \mu \mathrm{m}$ Phaeographis caesioradians

11a Lirellae apically carbonized, spores transversely septate, 31- 45 x 7-8 $\mu \mathrm{m}$ no lichenic acids detected Phaeographis intricans

$11 \mathrm{~b}$ Lirellae laterally to completely carbonized Graphis glaucescens

12a Lirellae laterally carbonized 12

12b Lirellae completely carbonized 13

13a Hymenium inspersed 27

13b Hymenium clear 14

14a Hymenium without pigment 18

14b Hymenium with pigment 15

15a Lirellae negrosina-morph, large ascospores, 78-96 x 21-24 $\mu \mathrm{m}$

$15 \mathrm{~b}$ Lirellae different types, spores not as large Allographa pilarensis

$16 \mathrm{a} \mathrm{K}+\mathrm{Y}$, stictic acid present 16

$16 \mathrm{~b} \mathrm{~K}-$, stictic acid absent Graphis leptocarpa

17a Lirellae negrosina-morph, disc not widely opened, $\mathrm{K}+$ green (Isohypocrelline present) Graphis lineola

$17 \mathrm{~b}$ Lirellae irregularly branched, widely opened disc, $\mathrm{K}+$ green (Isohypocrelline present) Graphis persicina

18a Ascospores muriform Graphis sp. 1

18b Ascospores transversely septate 19 
19a Lirellae hossei-morph with basal thalline margin

$19 \mathrm{~b}$ Lirellae lineola-morph with lateral thalline margin Graphis nanodes

20a Norstictic acid present, $\mathrm{K}+$ red Graphis analoga

20b Norstictic acid absent, KGraphis consimilis

21a P-, protocetraric acid absent 22

$21 \mathrm{~b} \mathrm{P}+$, protocetraric acid present 26

22a Stictic acid present, $\mathrm{K}+$ Graphis dendrogramma

22b Stictic acid absent 23

23a Labia pruinose 24

23b Labia non-pruinose or rarely thinly white-pruinose 25

24a Disc exposed, scripta-morph Graphis sundarbanensis

24b Disc concealed, caesiella-morph Graphis furcata

$25 \mathrm{a} \mathrm{K}+$ red, norstictic acid present Graphis cincta

$25 \mathrm{~b} \mathrm{~K}$ - norstictic acid absent Graphis pinicola

26a Disc concealed Graphis sp. 2

26b Disc open Graphis distincta

27a Labia striae Graphis nilgiriensis

27b Labia entire 28

28a $\mathrm{K}+\mathrm{Y}$, stictic acid present 29

$28 \mathrm{~b}$ K-Y, stictic acid absent Graphis immersicans

29a Disc exposed Graphis modesta

$29 \mathrm{~b}$ Disc concealed 30

30a Lirellae caesiella -morph Graphis imshaugii

30b Lirellae hossei-morph Allographa fujianensis

31a Ascocarp erumpent to prominent with thick thalline margin and narrow pore (ocellularioid), with apically carbonized columella, $\mathrm{K}+$ yellow, stictic acid

Ocellularia lumbschii

31b Ascocarp not showing same features, with or without lichenic acids

32a Ascocarp immersed-erumpent and open by irregular marginal lobes that remain erect or break apart (leprocarpoid), disc pruinose, ascospores large, no lichenic acids detected

Chapsa indica

32b Ascocarp immersed-erumpent to prominent, with free excipulum and distinct double margin, thalline margin bulging and entire (lepadinoid)

33a Inner excipulum thin, entire to slightly split, concolorous with the thallus, $\mathrm{K}+$ yellow, with stictic acid, spores medium, transversely septate Austrotrema bicinctulum

33b Inner excipulum thick, apothecial disc flesh-colored, spores larger, muriform, no lichenic acids detected

Thelotrema adjectum 
dark brown, flat disc, hymenium inspersed. Ascospores are hyaline to light brown, oblong muriform, $24-29 \times 7-8 \mu \mathrm{m}, 6-18$ x 2-4 locules. No lichen acid detected. (Fig. 3j)

\section{Conclusion and Recommendations}

Over-all, there is a low number of Graphidaceae species collected in western Pangasinan. The presence of new records signifies that there are still undiscovered species in the area. Further survey of the Graphidaceae microlichens in the whole Pangasinan province should be undertaken.

\section{Acknowledgments}

The researchers would like to express their gratitude to Department of Environment and Natural Resources-Region 1 for the granting of gratuitous permits, Commission on Higher Education for the dissertation grant given to the first author, local government units of western Pangasinan for their assistance during the field surveys and the Pangasinan State University-Lingayen Campus for the laboratory assistance.

\section{Literature Cited}

Aprile, G.G., I. Catalano, A. Migliozzi \& A. Mingo, 2011. Monitoring epiphytic lichen biodiversity to detect environmental quality and air pollution: the case study of Roccamonfina Park (Campania Region-Italy). Air Pollution -New Developments. InTech, 10: 228-244.

Aptroot, A. \& L. Sparrius, 2011. Pictures of tropical lichens (n.d). Retrieved from http://www.tropicallichens.net/ about.aspx

Archer, A.W., 2006. Key and checklist for the lichen family Graphidaceae (lichenized Ascomycota) in the Solomon Islands. Systematics and Biodiversity, 5(1): 9-22.

Archer, A.W., 2009. Graphidaceae. Flora of Australia, 57: 84194.

Asta, J., W. Erhardt, M. Ferretti, F. Fornasier, U. Kirschbaum, P.L. Nimis, O.W. Purvis, S. Pirintsos, C. Scheidegger, C. van Haluwyn \&V. Wirth, 2002. Mapping lichen diversity as an indicator of environmental quality, In: Nimis, P.L., C. Scheidegger and P.A, Wolseley (ed.). Monitoring with Lichens - Monitoring Lichens. Kluwer Academic Publishing, Dorderecht, The Netherlands. pp. 273-279

Bawingan, P.A., A. Pinas, R. Amoncio, D. Amilao, R. Beniking, M.A. Caliway, N.K. Lagarteja, W.T. Fajardo, C.H. Park \& J.-S. Hur, 2014. Diversity and adaptive features of corticolous lichens in the Hundred Islands, Philippines. Philippine Journal of Systematic Biology, 8: 46-62.
Benatti, M., 2012. A review of the genus Bulbothrix Hale: the species with medullary norstictic or protocetraric acids. MycoKeys, 2: 1-28.

Brodo, I.M. \& N.A. Sloan, 2004. Lichen zonation on coastal rocks in Gwaii Haanas National Park Reserve, Haida Gwaii (Queen Charlotte Islands), British Columbia. Canadian Field-Naturalist, 118: 405-424. Retrieved from http:// www.canadianfieldnaturalist.ca/index.php/cfn/article/ viewFile/11/1302

Buaruang, K., K. Boonpragob, P. Mongkolsuk, E. Sangvichien, K. Vongshewarat, W. Polyiam, A. Rangisruji, W. Saipunkaew, K. Naksuwankul, J. Kalb, S. Parnmen, E. Kraichak, P. Phraphychamnong, S. Meesim, T. Luangsuphabool, P. Nirongbut, V. Poengsungboen, N. Duangphui, M. Sudamuk, S. Phokaeo, M. Molsil, A. Aptroot, K. Kalb, R. Lücking \& T. Lumbsch, 2017. A new checklist of lichenized fungi occurring in Thailand. MycoKeys, 23: 1-91.

Cáceres, M.E.S., R. Lücking \& G. Rambold, 2007. Phorophyte specificity and environmental parameters versus stochasticity as determinants for species composition of corticolous crustose lichen communities in the Atlantic rain forest of northeastern Brazil. Mycological Progress, 6: 117136.

Castello, M., \& N. Skert, 2005. Evaluation of lichen diversity as an indicator of environmental quality in the North Adriatic submediterranean region. Science of the Total Environment, 336: 201-214.

da Silva Cáceres, M.E., 2006. The Corticolous Crustose and Microfoliose Lichens of Northeastern Brazil-Diversity, Ecology, and Conservation. Universität Beyreuth Doctoral dissertation, $176 \mathrm{pp}$.

Elix, J.A., 1992. Lichen chemistry. Flora of Australia, 54: 2329.

Frisch, A., K. Kalb, \& M. Grube, 2006. Contributions towards a new systematics of the lichen family Thelotremataceae. Bibliotheca Lichenologica, 92: 1-539.

Fritz, Ö., M. Niklasson, \& M. Churski, 2009. Tree age is a key factor for the conservation of epiphytic lichens and bryophytes in beech forests. Applied Vegetation Science, 12 (1): 93-106.

Hale, M.E., 1967. The Biology ofLlichens. London: Edward Arnold Ltd., $176 \mathrm{pp}$.

Joshi, S., T.T. Nguyen, N.A. Dzung, U. Jayalal, S.O. Oh \& J.S. Hur, 2013. New records of corticolous lichens from Vietnam. Mycotaxon, 123(1): 479-489.

Joshi, S., D.K. Upreti, P.K. Divakar, T.H. Lumbsch \& R. Lücking, 2018. A re-evaluation of thelotremoid Graphidaceae (lichenized Ascomycota: Ostropales) in 
India. The Lichenologist, 50(6): 627-678.

Joshi, S., D.K. Upreti, S.O. Oh, T.T. Nguyen, A.D. Nguyen \& J.S. Hur, 2015. New records of crustose lichens and a lichenicolous Arthonia from Vietnam. Mycotaxon, 130(2): 329-336.

Kalb, J., W. Polyiam, E.R. Rivas-Plata, P.A. Bawingan, K. Kalb \& R. Lücking, 2016. 'Missing links' alive? Novel taxa represent morphological transitions between distinctive phenotypes among extant Graphidaceae (lichenized Ascomycota: Ostropales). Phytotaxa, 268(2), 110-122.

Kłos, A., M. Rajfur, M. Wacławek \& W. Wacławek, 2009. 137Cs transfer from local particulate matter to lichens and mosses. Nukleonika, 54: 297-303.

Lücking, R., 2009. The taxonomy of the genus Graphis sensu Staiger (Ascomycota: Ostropales: Graphidaceae). The Lichenologist, 41: 319-362.

Lücking, R., A.W. Archer \& A. Aptroot, 2009. A world-wide key to the genus Graphis (Ostropales: Graphidaceae). The Lichenologist, 41: 363-45.

Lücking, R., B.P. Hodkinson \& S.D. Leavitt, 2017. The 2016 classification of lichenized fungi in the Ascomycota and Basidiomycota-approaching one thousand genera. The Bryologist, 119(4): 361-417.

Lücking, R., M.K. Johnston, A. Aptroot, E. Kraichak, J.C. Lendemer, K. Boonpragob, M.E.S. Cáceres, D. Ertz, L.I. Ferraro, Z.-F. Jia, K. Kalb, A. Mangold, L. Manoch, J.A. Mercado-Díaz, B. Moncada, P. Mongkolsuk, K. Butsatornpapon, S. Parnmen, R.N. Peláez, V. Poengsungnoen, E. Rivas Plata, W. Saipunkaew, H.J.M. Sipman, J. Sutjaritturakan, D. van den Broeck, M. von Konrat, G. Weerakoon \& H.T. Lumbsch, 2014. One hundred and seventy-five new species of Graphidaceae: closing the gap or a drop in the bucket? Phytotaxa, 189(1): 7-38.

Lücking, R. \& K. Kalb, 2018. Formal instatement of Allographa (Graphidaceae): how to deal with a hyperdiverse genus complex with cryptic differentiation and paucity of molecular data. Herzogia, 31(p1): 535-561.

Lücking, R. \& A. Lücking, 1996. 5. Foliicoulus bryophytes and lichens. In: Gradstein, S.R., P. Hietz, R. Lücking, A. Lücking, H.J.M. Sipman, H.F.M. Vester, J.H.D. Wolf and E. Gardette, How to sample the epiphytic diversity of tropical rain forests, Ecotropica, 2: 67-72.

ücking, R., A. Mangold \& H.T. Lumbsch, 2016. A worldwide key to species of the genera Myriotrema and Glaucotrema (lichenized Ascomycota: Graphidaceae), with a nomenclatural checklist of species published in Myriotrema. Herzogia, 29(2): 493-514.

Lücking, R., A. Tehler, F. Bungartz, E. Rivas-Plata \& H.T.
Lumbsch, 2013. Journey from the West: did tropical Graphidaceae (lichenized Ascomycota: Ostropales) evolve from a saxicolous ancestor along the American Pacific coast? American Journal of Botany, 100(5): 844-856.

Lumbsch, H. T., T. Ahti, S. Altermann, G.A. De Paz, A. Aptroot, U. Arup, ... \& C.R. Bjoerk, 2011. One hundred new species of lichenized fungi: a signature of undiscovered global diversity. Phytotaxa, 1-127.

Lumbsch, H. T., S. Parnmen, E. Kraichak, K.B. Papong, \& R. Lücking, 2014. High frequency of character transformations is phylogenetically structured within the lichenized fungal family Graphidaceae (Ascomycota: Ostropales). Systematics and Biodiversity, 12(3): 271-291.

Mangold, A., M.P. Martin, R. Lücking \& H.T. Lumbsch, 2008. Molecular phylogeny suggests synonymy of Thelotremataceae within Graphidaceae (Ascomycota: Ostropales). Taxon, 57: 476-486.

May, P.F., I.M. Brodo \& T.L. Esslinger, 2001. Identifying North American lichens: A guide to the literature. Retrieved from http://www2.huh.harvard.edu/collections/lichens/guide/ guidetoliterature.html\#microcrystal

Medeiros, I., D.E. Kraichak, R. Lücking, A. Mangold \& H.T. Lumbsch, 2017. Assembling a taxonomic monograph of tribe Wirthiotremateae (lichenized Ascomycota: Ostropales: Graphidaceae). Fieldiana Life and Earth Sciences, 9(1): 131.

Meng, Q.F., \& J.C. Wei, 2008. A lichen genus Diorygma (Graphidaceae, Ascomycota) in China. Mycosystema, 27(4): 525-531.

Messuti, M. I., P.L. Codesal, A. Mangold, R. Lücking \& H.T. Lumbsch, 2010. New or interesting Chapsa and Topeliopsis species (Ascomycota: Ostropales) from Argentina. The Lichenologist, 42(2): 191-195.

Nayaka, S., 2014. Methods and techniques in collection, preservation and identification of lichens. Plant Taxonomy and Biosystematics-Classical and Modern Methods. New India Publishing Agency, New Delhi. pp. 101-128.

Nimis, P. L., G. Lazzarin \& D. Gasparo, 1991. Lichens as bioindicators of air pollution by $\mathrm{SO}_{2}$ in the Veneto region (NE Italy). Studia Geobotanica, 11: 3-76.

Nimis, P. L., G. Lazzarin, A. Lazzarin \& N. Skert, 2000. Biomonitoring of trace elements with lichens in Veneto (NE Italy). Science of the Total Environment, 255(1-3): 97-111.

Parnmen, S., E. Rivas-Plata, R. Lücking, P.A. Bawingan, A. Lisangan-Tabaquero, , K. Kalb \& H.T. Lumbsch, 2012. The lichen family Graphidaceae in the Philippines. In: The 7th International Association for Lichenology Symposium 2012, "Lichens: from genome to ecosystems in a changing world. Book of Abstracts, $99 \mathrm{pp}$. 
Rivas-Plata, E. R. \& R. Lücking, 2013. High diversity of Graphidaceae (lichenized Ascomycota: Ostropales) in Amazonian Perú. Fungal Diversity, 58(1): 13-32.

Rivas-Plata, E., R. Lücking \& H.T. Lumbsch, 2008a. Corticolous lichens of the tropics - Graphidaceae. The Field Museum, Chicago, Illinois, USA. Retrieved from https://fieldguides.fieldmuseum.org/sites/default/files/rapid -color-guides-pdfs/355_GRAPHIDACEAE_1.pdf

Rivas-Plata, E.R., R. Lücking \& H.T. Lumbsch, 2008b. When family matters: an analysis of Thelotremataceae (lichenized Ascomycota: Ostropales) as bioindicators of ecological continuity in tropical forests. Biodiversity and Conservation, 17(6): 1319-1351.

Rivas-Plata, E.R., R. Lücking \& H.T. Lumbsch, 2012. A new classification for the family Graphidaceae (Ascomycota: Lecanoromycetes: Ostropales). Fungal Diversity, 52(1): 107-121.

Rivas-Plata, E.R., R. Lücking, H.J. Sipman, A. Mangold, A. Kalb \& T. Lumbsch, 2010. A world-wide key to the thelotremoid Graphidaceae, excluding the OcellulariaMyriotrema-Stegobolus clade. The Lichenologist, 41: 139185.

Rivas-Plata, E.R., H.J. Sipman \& R. Lücking, 2014. Five new thelotremoid Graphidaceae from the Philippines. Phytotaxa, 189(1): 282-288.

Schumm, F. \& A. Aptroot, 2012. A microscopical atlas of some tropical lichens from SE-Asia (Thailand, Cambodia, Philippines, Vietnam): Volume: 2. BoD-Books on Demand, 1(184): 1-859.

Singh, A., 2011. Herbalism, Phytochemistry and Ethnopharmacology. CRC Press, boca Raton, Florida, 281

pp.

Sipman, H.J.M., 2005. Key to crustose, not foliicolous lichens. Retrieved on April 10, 2010 from http://www.bgbm.org/ sipman/keys/neokeyG.htm.

Sipman, H.J.M., 2008a. Key to the genera of Graphidaceae, provisional determination keys for the Graphidales of Costa Rica. Retrieved from http://www.bgbm.org/sipman/keys/ neokeyG.htm.

Sipman, H.J.M., 2008b. Key to the corticolous species of Thelotremataceae. Retrieved from http:/www.bgbm.org/ sipman/keys/neokeyG.htm

Sipman, H.J., R. Lücking, A. Aptroot, J.L. Chaves, K. Kalb \& L.U. Tenorio, 2012. A first assessment of the Ticolichen biodiversity inventory in Costa Rica and adjacent areas: the thelotremoid Graphidaceae (Ascomycota: Ostropales). Phytotaxa, 55(1): 1-214.

Sohrabi, M., R. Lücking \& H.T. Lumbsch, 2014. One hundred and seventy five new species of Graphidaceae - a special issue of Phytotaxa. Phytotaxa, 189(1):5-6.

Staiger, B., 2002. Die Flechtenfamilie Graphidaceae. Studien in Richtung einer naturlicheren Gliederung. Bibliotheca Lichenologica, 85: 1-526.

Staiger, B., 2005. How to arrange the diversity of a tropical lichen family? Archives des Sciences, 58: 53-62.

Tabaquero, A., P.A. Bawingan \& R. Lücking, 2013. Key and checklist of Graphidaceae lichens in the Kalahan Forest Reserve, Nueva Vizcaya, Philippines. Philippine Journal of Systematic Biology, 7: 22-38.

The Catalogue of Life Partnership, 2018. Catalogue of Life. Checklist dataset https://doi.org/10.15468/rffz4x accessed via GBIF.org on 2019-02-20. 